Jana S. Rošker

\title{
Epistemologija modernega konfucijanstva na primeru druge generacije - med razumom in intuicijo
}

\begin{abstract}
Ključne besede: moderna kitajska epistemologija, spoznavna teorija, Xiong Shili, Liang Shuming, Feng Youlan, Fang Dongmei, Mou Zongsan, Xu Fuguan, Tang Junyi, razum, intuicija
\end{abstract}

DOI: 10.4312/ars.10.1.165-188

\section{Uvod}

Pričujoči članek obravnava epistemološke teorije osrednjih predstavnikov intelektualne struje modernega konfucijanstva, ki se je oblikovala na Kitajskem na pragu prejšnjega stoletja.

Že na samem začetku je treba izpostaviti, da je v okviru tradicionalne kitajske filozofije ločnica med epistemologijo in ontologijo zabrisana, saj temeljijo diskurzi kitajske idejne zgodovine na predpostavki, po kateri obstaja samo tisto, kar je možno spoznati ali je že bilo spoznano:

$\mathrm{V}$ tradiciji kitajskega holizma je ontologija neločljivo povezana $\mathrm{Z}$ epistemologijo, kajti v tovrstnem pogledu na svet je vsak spoznavni objekt hkrati tudi samo spoznanje. Način našega bivanja je torej neločljivo povezan z našim spoznavanjem le-tega. Ker je ta povezava obojestranska oziroma vzajemna, odnos med obema ni odnos enostranske odvisnosti in določenosti, temveč gre pri njem za interakcijo, ki vključuje vzajemno soodvisnost; zato ne moremo trditi, da gre pri tem za solipsistično konceptualiziranje sveta. Isto kot za eksistenco obstoječega sveta velja za njegovo percepcijo in interpretacijo. Tudi njiju ni mogoče ločevati od celostnega, a nenehno spremenljivega in popolnoma individualiziranega obstoja objektov spoznanja; to se jasno odraža v teoretskem sistemu t. i. ontohermenevtike, ki jo je razvil Chungying Cheng, predstavnik tretje generacije modernega konfucijanstva (Ng On-cho, 2011, 152). ${ }^{1}$

1 Glej tudi razdelek 2.3 »Ontoepistemologija « v mojem prispevku o kitajski epistemologiji v Stanford Encyclopedia of Philosophy (Rošker, 2015, 2.3). 
Prispevek se osredotoča predvsem na spoznavne metode $v$ delih $t$. i. druge generacije tega gibanja, tj. na filozofe, ki so od leta 1950 do konca prejšnjega stoletja zaradi političnih in ideoloških razmer, ki so takrat prevladovale na kitajski celini - živeli in delovali na Tajvanu in v Hong Kongu. Poleg dela štirih filozofov, Mou Zongsana, Tang Junyija, Fang Dongmeija in Xu Fuguana, bomo v uvodnem delu predstavili tudi temeljne epistemološke značilnosti pripadnika prve generacije Xiong Shilija, saj gre za teoretika, ki je bil učitelj večine filozofov ${ }^{2}$ druge generacije in je močno vplival na nadaljnji razvoj teorij modernega konfucijanstva.

Ker gre pri modernem konfucijanstvu za idejno strujo, ki si je prizadevala za vzpostavitev sinteze med lastno miselno tradicijo in evropskimi teoretskimi sistemi oziroma za posodobitev te tradicije in njeno prilagoditev razmeram modernih družb, so njeni predstavniki tudi $\mathrm{v}$ svojih epistemoloških diskurzih izhajali iz specifičnih posebnosti tradicionalne kitajske epistemološke miselnosti. ${ }^{3}$ Epistemologija kot natančno razmejena filozofska disciplina na Kitajskem nikoli ni obstajala. Pri njej gre namreč za koncept, ki je bil na Kitajsko »uvožen« iz Evrope; zato so njegove vsebinske konotacije tesno povezane $\mathrm{z}$ miselnimi vzorci, ki so prevladali v evropski idejni zgodovini. V okviru prevladujočih evropskih epistemologij je znanje razumljeno kot nekaj, kar pridobivamo s pomočjo mišljenja, kar pomeni, da je osnovano na znanstvenem videnju sveta. $\mathrm{V}$ tradicionalni kitajski miselnosti pa se je to vprašanje razumevalo v veliko širšem smislu; znanje je bilo v tem okviru nekaj, kar je (v prvi vrsti) povezano z moralnimi vsebinami in česar ni možno ločevati od (družbene) prakse.

Debata o epistemoloških razsežnostih klasičnih in sodobnih kitajskih besedil ter njihovi vlogi $\mathrm{v}$ kontekstu tradicionalne kitajske miselnosti se $\mathrm{v}$ sodobnih študijah vse uspešneje odvija $\mathrm{v}$ znamenju ponovnega odkrivanja in uporabe specifičnih tradicionalno kitajskih metodoloških pristopov in tradicionalnih kategorij (Rošker, 2008, 14). Kitajska epistemologija obravnava probleme, h katerim sodijo "pravilno« spoznavanje določenega objekta in s tem tudi možnost popolnega dojetja Poti (dao); razmerje med znanjem in modrostjo na eni ter odnos med znanjem in moralo na drugi strani; možnost jezika kot posredovalca znanja ter odnos med znanjem in izvajanjem (xing) (ibid.). Po drugi strani so bile vse razvojne struje starokitajske epistemologije osnovane tudi na strukturno urejenem holističnem videnju sveta in zakoreninjene $\mathrm{v}$ aksioloških premisah.

2 Xiongovi študentje so bili kar trije od štirih predstavnikov druge generacije, namreč Mou Zongsan, Tang Junyi in Xu Fuguan.

3 Epistemološka miselnost (renshilun sixiang 認識論思想) je terminus technicus, ki se je v zadnjih desetletjih uveljavil znotraj sodobne kitajske filozofije, ki temelji na predpostavki, po kateri kitajska idejna tradicija ni poznala epistemologije kot strogo razmejene in določene znanstvene discipline, vendar vsebuje veliko epistemološkega mišljenja, ki je vidno v delih večine pomembnih kitajskih filozofov oziroma teoretikov. 
Vse to je jasno vidno že v teoretskih delih Xiong Shilija, ki je bil, kot rečeno, učitelj večine filozofov druge generacije modernega konfucijanstva. Zato si najprej nekoliko podrobneje oglejmo osrednje iztočnice Xiongove epistemološke misli.

\section{Xiong Shilijeva epistemološka izhodišča}

Xiong je bil začetnik oziroma utemeljitelj modernega konfucijanstva (xin ruxue) ter prvi filozof, ki je na osnovi klasičnih konfucijanskih konceptov razvil svoj lastni, razmeram nove dobe prilagojeni idejni sistem.

Po svojem idejnem preobratu od budizma h konfucijanskim izhodiščem je Xiong Shili vzpostavil nov kozmološki sistem, ki je bil v skladu s temelji tradicionalnega kitajskega holizma. $\mathrm{V}$ osrednjem kategorialnem vzorcu, ki ga je $\mathrm{v}$ tem sistemu vseskozi uporabljal, je uporabil tradicionalno komplementarno dialektiko, ki se odraža tudi v vseh idejnih strujah konfucijanstva. Xiong je namreč zavračal budistično stališče strogega ločevanja med absolutno, nespremenljivo resničnostjo dharmične narave (faxing) ter spreminjajočim se in nekontinuiranim svetom pojavnosti oziroma dharmičnih pojavnosti (faxiang). Tovrstna konceptualna razločitev je po njegovem mnenju tipična za večino filozofij in je ne najdemo zgolj $\mathrm{v}$ indijski oziroma budistični, temveč tudi v zahodni in kitajski tradiciji. V zahodni filozofiji gre pri tem za razločevanje med substanco (noumenon) in fenomenom (phenoumenon), ki ga najdemo zlasti v platonistični tradiciji. Ta razločitev se odraža na področjih lingvistike (osebek in povedek), psihologije (duša in telo, razum in čustva), epistemologije (prepričanje in znanje, čutni vtisi in razumska analiza) ter metafizike (popolnost in nepopolnost, večnost in minljivost, resnično in lažno). $\mathrm{V}$ kitajski tradiciji na tovrstno razlikovanje naletimo v neokonfucijanskih dualizmih in $\mathrm{v}$ njihovih poskusih preseganja holistične tradicije $\mathrm{v}$ smislu ločevanja idejne (li) in materialne (qi) sfere.

V svoji argumentaciji se Xiong Shili poslužuje tradicionalnih konfucijanskih konceptov. Tako absolutno, (objektivno obstoječo) resničnost poimenuje z izrazom ti (esenca), ${ }^{4}$ spremenljivi svet pojavnosti pa $\mathrm{z}$ analognim terminom, ki v okvirih konfucijanske tradicije vselej služi kot bipolarno nasprotje esence, tj. yong (funkcija). V skladu s komplementarnim načelom, ki prihaja do izraza že v Knjigi premen (Yi jing), ${ }^{5}$ poudarja temeljno enovitost tega binarnega para.

4 Yu Jiyuan $\mathrm{v}$ angleščini koncept $t i$ poimenuje $\mathrm{z}$ izrazom 'original reality', opozarja na nevarnost običajnih prevodov tega termina: "The word ' $t i$ ' is generally translated as 'substance'. But this will lead one to read an Aristotelian conceptual framework into Xiong“ (Yu, 2002, 132).

5 Xiong je Knjigi premen posvetil precej svojega raziskovalnega dela, katerega izsledke je objavljal v različnih akademskih člankih. Večino teh najdemo v 3. knjigi Xiongovih zbranih del. 
Bistveno razliko med zahodnimi interpretacijami in svojo ontologijo modernega konfucijanstva vidi Xiong v različnem dojemanju zahodne »objektivne resničnosti« oziroma njegovega koncepta »esence $(t i)$ «: medtem ko je objektivna resničnost zahodnim filozofijam entiteta "zunanjosti«, dostopna prek konstrukcij razuma, Xiongova esenca ni zgolj osnovni razlog vseobsežnega bivanja, temveč je hkrati tudi bistvo vsakršnega bivanja, saj je identična $\mathrm{z}$ individualnim duhom (ali z individualno zavestjo) vsakega posameznika.

Po svojem bistvu je Xiongova epistemologija tradicionalno konfucijanska in kot taka neločljivo povezana z etiko. Most, ki povezuje obe področji, je stališče, da kozmos in človek tvorita enoto in da je torej kozmična zavest enaka človeški. Izvorna resničnost se kaže v vsem, kar biva, in je v vsem tem tudi konkretno prisotna. Človeške zavesti so manifestacije izvorne zavesti znotraj ljudi. Zato življenje ljudi in véliko življenje univerzuma ni dvoje (Yu, 2002, 139).

Xiong izhaja iz predpostavke, da je esenca bivajočega $(t i)$ identična s človeško srčno zavestjo (xin). Iz tega sledi, da je edina pot, ki vodi k prepoznavanju te esence (tj. objektivne resničnosti in hkrati poslednjega smisla bivanja), spoznavanje lastnega duha. V tem spoznavnem procesu posameznik hkrati neguje svojo osebnost in kultivira svoje kreposti. Xiong Shilijeva osnovna ontološka teza enovitosti esence in funkcije se zato logično odraža tudi v njegovi teoriji zavesti. Človeški duh vsebuje dva tipa zavesti: prvega, ki ustreza kozmični esenci, poimenuje z izrazom apriorna zavest (ben xin). Drugi tip zavesti, ki ga v ontološkem pogledu enači s funkcijo (yong), imenuje priučena zavest (xi xin). Priučena zavest je po svojem bistvu iluzorna, tako kot snovnost in pojavnost stvarnosti, ki ji ustreza. Ker pa je človeška predstavna sposobnost znotraj vsakdanje stvarnosti omejena in vezana na individualno sebstvo, se nam predoča kot resnična, prav tako kot konkretne stvari, ki jih dojema (Xiong, 1992, 278).

Apriorno zavest posameznika Xiong Shili enači z njegovo prvobitno, resnično »naravo« (xing). Priučena zavest je opredeljena s specifičnimi pogoji življenja, s katerim se sooča prek mišljenja, volje in čustvovanja. Medtem ko je prva osmišljena in neposredno povezana $\mathrm{z}$ dejanskostjo bivanja kot celote, deluje slednja pod predpostavko ločevanja duha in zunanjega sveta ter je hkrati obremenjena $\mathrm{z}$ egocentričnimi predsodki in puhlimi, lažnimi željami. Medtem ko služi priučena zavest kot orodje, ki nam pomaga pri preživetju v svetu konkretnih pojavnosti, nam prepoznavanje oziroma podoživljanje apriorne zavesti in njene identičnosti z esenco bivajočega to preživetje osmisli. Predpostavka potrebe po osmišljenju preživetja, ki naj bi človeka ločevala od živali, ima v vseh konfucijanskih teorijah osrednji pomen. Pot, ki vodi do tega osmišljenja, spoznavna metoda, ki nas privede do doživetja celovitosti z esenco bivanja, je pri Xiong Shiliju metoda introspektivne samorefleksije. 
Vzporedno $\mathrm{z}$ dihotomijami esence in funkcije oziroma apriorne in priučene zavesti je Xiong Shili v svoji spoznavni teoriji vzpostavil tudi diferenciacijo med dvema kategorijama spoznanja. Pri prvi, ki tvori epistemološko analogijo z esenco in apriorno zavestjo, gre za kategorijo kvalitativnega spoznanja (xingzhi). Drugi tip spoznanja, ki ustreza funkciji kvalitativnega spoznanja oziroma priučeni zavesti, Xiong imenuje kvantitativno spoznanje (liangzhi) (ibid., 249).

V naslednjem koraku razvoja svojega epistemološkega sistema je Xiong Shili kvantitativno spoznavanje povezal z znanstvenim, kvalitativno pa s filozofskim oziroma metafizičnim. Na ta način je poskusil opredeliti razmerje med konfucianizmom in sodobno znanostjo. Kvantitativno spoznavanje je primerno in učinkovito orodje za raziskovanje konkretne stvarnosti, ki opredeljuje naš vsakdan. Vendar moramo poznati njegove meje in paziti, da ga ne uporabljamo tudi kot spoznavni instrument razumevanja ontoloških in metafizičnih danosti, kajti s tem esenco bivanja reduciramo na funkcijo zunanjega objekta spoznanja. Zato Xiong Shili opozarja na potrebo po ločevanju znanosti in metafizike.

Vendar se Xiong Shilijeve epistemološke izpeljave po svojem bistvu vendarle razlikujejo od Kantovih. Xiong namreč vseskozi poudarja, da je esenco (ti) v smislu absolutne resničnosti možno spoznati. Izhaja iz predpostavke, po kateri ta poslednja resnica ni entiteta, ki bi bila zunaj (in neodvisno od) naše zavesti. Bistvo ontologije se nam po Xiongovi teoriji razkriva prek razumevanja lastnega bistva. Izvorna esenca bivanja je namreč skrita v vsakem od nas, zato ne lebdi nekje v objektni sferi zunanjosti; Xiongova resnica torej ni samostojni zunanji objekt, ki bi čakal, da ga razkrijemo in obvladamo s pomočjo kognitivnih tehnik našega razuma. Pot, ki vodi do njenega prepoznanja, je introspektivna (fanji tiren); v procesu samorefleksije (fanqiu zishi), v potapljanju vase, se nam resnica esence bivajočega razkrije sama od sebe. Spoznavna metoda introspekcije po Xiong Shiliju torej ni nič drugega kot podoživljanje izvorne zavesti s pomočjo ponotranjene intuicije, tj. $\mathrm{z}$ uporabo kvalitativnega znanja.

Za razliko od prevladujočega trenda $\mathrm{v}$ konservativni struji takrat še preostalih zagovornikov konfucijanstva Xiong nikakor ni zavračal znanstvenega diskurza kot takega. Prav nasprotno, zagovarjal je stališče, da ima znanost velik pomen kot instrument, ki človeštvu omogoča napredek in blagostanje. S tem postane znanost tudi nova možnost izboljšanja pogojev za individualno nego osebnosti posameznikov, kar naj bi zopet pozitivno vplivalo na harmonizacijo celotne družbe. Ta nova možnost kultivacije pa hkrati skriva $\mathrm{v}$ sebi past egoizma in površnega navezovanja posameznikov na materialne dobrine. Oboje, tako nega osebnosti kot tudi egoizem in lažne želje, je namreč možen produkt napredka in blagostanja. Zato Xiong v znanosti in tehnologiji vidi močno in vplivno orodje, ki ga je treba uporabljati z vso 
pazljivostjo in etično odgovornostjo. Druga nevarnost, na katero Xiong Shili opozarja v zvezi z znanostjo, je fragmentarnost njenih epistemoloških pristopov k raziskovanju stvarnosti. Znanstvenim raziskavam se je torej treba posvečati zgolj prek priučene zavesti in kvantitativnega spoznavanja. Če se torej poskušamo znanstveno lotevati celovitosti stvarnosti, bomo s tem povzročili razpršitev oziroma fragmentalizacijo naše apriorne zavesti. Tudi ta nevarnost lahko po Xiongu vodi do tega, da izgubimo smernice etičnega osmišljenja našega življenja, da spregledamo kažipote, ki vodijo k negi osebnosti in kultivaciji naših kreposti, ter se izgubimo na brezpotju površnih nagibov hotenja. Ker torej znanost sama po sebi ne more razrešiti problema smisla človeškega življenja, mora biti podrejena filozofskemu osmišljenju spoznanja. Xiong Shilijevo sprejemanje in zagovarjanje znanosti izhaja torej prav iz njegovega prepričanja o tem, da gre pri njej za učinkovit spoznavni instrument, ki deluje v okviru popolnoma drugačnega diskurza kot filozofija, ki je pristojna za etiko in metafiziko. Fragmentna narava kvantitativnega spoznavanja sama po sebi še ne pomeni, da ljudje, ki se mu posvečajo, nujno izgubijo smisel in splošne etične smernice svojega življenja. Prav tako ne drži, da naj bi znanost sama po sebi nujno vodila do duhovne revščine v smislu prevladovanja materialnih želja in potrošniških strasti.

Poleg tega Xiong poudarja, da tudi znanstveni diskurz sam po sebi ni opredeljen zgolj $\mathrm{z}$ analizo, temveč tudi s sintezo; in celo intuicija igra $\mathrm{v}$ njem precej pomembno vlogo (Yu, 2002, 141). Kot rečeno, je za preprečevanje njenih »negativnih stranskih učinkov« potreben etično osmišljeni nadzor kultivirane metafizike. Razmerje med znanostjo in filozofijo je po Xiongu torej komplementarno, enako kot razmerje med esenco in funkcijo.

Kljub temu Xiong vselej znova poudarja meje znanstvenega obravnavanja stvarnosti in mišljenja. Tu gre za meje, ki jih ne gre presegati; zato je razmerje med znanostjo in filozofijo sicer vzajemno, vendar je zanj filozofski (zlasti metafizični) diskurz primarnejši in pomembnejši.

Nikakor nisem proti razumskemu razmišljanju. Je zelo pomembno za obravnavanje in dognanje konkretnih posebnosti vsega obstoječega; $\mathrm{z}$ izčrpnim raziskovanjem njihovih razlik nas lahko privede do njihovega poenotenja. $Z$ opazovanjem in uporabo splošnih zakonitosti se lahko dokopljemo do mnogoterih spoznanj o najmanjših drobcih živo pisane stvarnosti. Iz izsledkov raziskovanja najmanjših podrobnosti konkretnega sveta pa zopet lahko sklepamo na naravo njegove celovitosti. ... Vendar uporabnosti razumskega mišljenja ne moremo razširjati v nedogled. Potem ko smo izčrpali spoznavanje zakonitosti, pridemo do skrajne točke, namreč do tja, kjer nam razmišljanje prav nič več ne pomaga. Vsi metafiziki bi se morali tega zavedati (Xiong, 1992, 357). 
Tu gre za logično izpeljavo specifičnega videnja načela komplementarnosti, ki se kot rdeča nit vleče skozi vso Xiong Shilijevo filozofijo. Vsako razmerje bipolarnih parov kljub vzajemni soodvisnosti vsebuje primarni pol, ki to vzajemno soodvisnost opredeljuje, določa in sploh omogoča: v razmerju med esenco in funkcijo je to prvi, $\mathrm{v}$ razmerju med priučeno in apriorno zavestjo pa slednji pol. In tako kot kvalitativno spoznanje določa in opredeljuje kvalitativno, bi morala tudi filozofija določati in opredeljevati znanost. Zato se je Xiong odločno postavil po robu težnji po scientifikaciji tradicionalne kitajske filozofije, ki je bila v intelektualnih krogih njegovih sodobnikov precej razširjena. Že v obravnavanju novega pragmatizma, ki se kaže tako v Hu Shijevem $^{6}$ kot tudi v Feng Youlanovem ${ }^{7}$ delu, smo videli, da je šlo pri tem predvsem za poskuse vzpostavitve znanstvene metodologije ter sistematične klasifikacije, ki bi ustrezala tradicionalnemu filozofskemu diskurzu. Ta naj bi nadomestila prejšnje filozofske misticizme ter vzpostavila sistematično, logično konsistentno in pregledno formalno ogrodje, $\mathrm{v}$ katerega bi bilo mogoče umestiti klasično kitajske, na načelu imanentne metafizike temelječe idejne sisteme. Toliko večji pomen so »novi intelektualci« prisojali scientifikaciji, torej zlasti vzpostavitvi logično utemeljene metodologije sodobnih teorij. Po njihovem mnenju naj bi torej znanstveni epistemični pristopi popolnoma nadomestili metode intuicije, introspekcije in podoživljanja apriornih vidikov zavesti. Xiong se je tej težnji uprl predvsem zaradi tega, ker je v filozofiji videl diskurz, ki se tako po svoji esenci kot po svoji funkciji bistveno razlikuje od znanstvenega. Medtem ko je prvi pristojen za formalno in tehnicistično obravnavo (ter smiselno in učinkovito obdelavo) stvarnosti, je slednji pomemben v vlogi etično osmišljene osnove tovrstnega obravnavanja stvarnosti. Formalizirana epistemologija znanosti namreč po Xiongovem mnenju ne more služiti kot kriterij razsojanja ali vrednotenja stvarnosti.

Ta Xiongova stališča glede različnih spoznavnih metod (predvsem glede razuma in intuicije) ter njihove uporabe so močno vplivala na vse predstavnike druge generacije modernega konfucijanstva, ki jih bomo nekoliko podrobneje predstavili, analizirali in interpretirali v naslednjih poglavjih pričujočega eseja.

\section{Razum in intuicija}

Večina modernih konfucijancev je prevzela tradicionalno kitajsko predpostavko, po kateri je moralno kultiviranje sebstva predpogoj za celostno spoznanje. Po tej predpostavki človeški spoznavni aparat ne razpolaga samo z racionalnimi mehanizmi,

$6 \quad \mathrm{Hu}$ Shi je bil osrednji predstavnik kitajskega razsvetljenskega gibanja iz prve polovice 20. stoletja, ki se je pričelo leta 1919 in je znano pod imenom »Gibanje četrtega maja«.

7 Feng Youlan je bil eden osrednjih predstavnikov prve generacije modernega konfucijanstva. 
temveč lahko uporabi tudi iracionalne dejavnike, kot so volja ali namera, želje in čustva.

Ločnico med razumom in intuicijo so pripadniki druge generacije modernega konfucijanstva, podobno kot Xiong Shili, ki je bil učitelj večine od njih, ponazarjali tudi kot ločnico, ki razmejuje filozofijo od znanosti. Četudi niso nasprotovali znanosti, pa so bili proti scientizmu in $\mathrm{v}$ njihovih delih pogosto naletimo na opazko, da znanost, ki je osredotočena na spoznavanje objektov naravnega, zunanjega sveta ter na izključno uporabo racionalnih in analitičnih metod, nikoli ne bo mogla razrešiti vprašanja smisla človeškega življenja ali vplivati na svetovni nazor ljudi (Han, Zhao, 1994, 169). Medtem ko znanost raziskuje dejstva, ima filozofija opraviti z raziskovanjem pomenov in vrednosti. Ločnica med razumom in intuicijo zato zanje ni bila zgolj ločnica med znanostjo in filozofijo (ali naravoslovjem in humanistiko), temveč tudi črta, ki razmejuje sfero pojavnosti od sfere vrednot.

Tradicionalna kitajska epistemologija je $\mathrm{v}$ veliki meri temeljila na metodi introspekcije in intuitivnega dojemanja resničnosti. ${ }^{8} \mathrm{~V}$ neokonfucijanstvu dinastij Song (960-1279) in Ming (1368-1644), na katerem temelji večina modernih konfucijanskih diskurzov, sta se izoblikovali dve šoli: prva, "realistična, " je znana pod imenom Šola strukture (lixue) ali Šola razuma (xingli xue) in se je oblikovala pod vplivom osrednjega srednjeveškega kitajskega filozofa Zhu Xija. V epistemološkem pogledu je poudarjala realistične metode spoznavanja stvarnosti in uvedla ustrezno metodo »raziskovanja stvari« (gewu). Drugo, ki je bolj osredotočena na solipsistične in intuitivne metode spoznavanja stvarnosti, imenujemo Šola srčne zavesti (xin xue). Nastala je pod vplivom osrednjega »idealističnega «" filozofa dinastije Ming Wang Yangminga. ${ }^{10}$ Četudi je imela slednja šola na večino modernih konfucijancev večji

8 Seveda to velja zgolj za prevladujoče diskurze. V kitajski idejni zgodovini najdemo tudi številne filozofske šole in posameznike, ki so se zavzemali za realistične, na razumu temelječe spoznavne metode in so metodo intuicije kritizirali oziroma negirali. V obdobju kitajske antike so $\mathrm{k}$ takim šolam sodili predvsem moisti in nomenalisti, v neokonfucijanstvu številni predstavniki Šole strukture (li xue), kasneje pa tudi predstavniki opozicije prevladujočih struj konfucijanstva in »novih metodologij«, ki so se zbrali pod okriljem akademije Vzhodnega gozda (Donglin shuyuan). Zelo nazorno kritiko prevladujočih intuitivnih metod najdemo v delu realističnega filozofa Wang Fuzhija (1619-1692), ki v svojih komentarjih k daoističnemu klasiku Laozi ne more skriti, kako trapaste se mu zdijo tovrstne metode: »Kako naj bi mi stvari enostavno, kar brez mojega truda, podeljevale znanje? Saj to je tako, kot bi se oprijel slepca in z njim hotel dohiteti konja v galopu. To je neumno zapravljanje energije. Temu ni tako. Le kje pod soncem naj bi bilo možno »ne izvajati kakršne koli prakse, pa se vendar dokopati do spoznanja, poimenovati stvari, ki jih ne zaznaš s čutili, in doseči popolnost brez delovanja«? (物授我知, 而我不勤, 乃知昔之遂亡子而追奔馬, 勞而愚矣。非 然, 則天下豈有 ‘不行而知, 不見而明, 不為而成’, 者哉? ) (Wang Fuzhi, Laozi Yan, v: Xia Zhentao, 1996, 372).

9 Dualistična razmejitev med idealizmom in materializmom za obravnavanje tradicionalne kitajske filozofije ni primerna, saj ločnica med materijo in idejo v metafizičnih razpravah kitajskih filozofov pogosto sploh ni prisotna in ni služila kot kriterij filozofskega razmišljanja.

10 Pri tem gre za vzdevek, pod katerim je Wang zaslovel. Njegovo pravo ime je Wang Shouren. 
vpliv kot Zhu Xijeva filozofija, je bil koncept razuma, ki v Wang Yangmingovi filozofiji (za razliko od Zhu Xijeve) tako rekoč ni bil prisoten, ${ }^{11}$ pomemben element njihovih filozofskih prizadevanj. Intuitivno prepoznavanje stvarnosti je pri obeh šolah tesno povezano s konceptom pra-znanja (liangzhi), ${ }^{12}$ ki predstavlja srž moralne narave znotraj vsake osebnosti.

Ker predstavlja koncept razuma enega idejnih temeljev modernizacije, so se moderni konfucijanci precej ukvarjali z vprašanjem sinizacije tega pojma, saj je večina od njih kljub negiranju scienticizma vendarle potrjevala (in delno celo poudarjala) pomen znanosti in tehnologije tudi za razvoj moderne kitajske družbe. $\mathrm{V}$ ta namen so poskušali najti sintezo med tradicionalnim konfucijanskim konceptom intuitivnega spoznavanja in idejnimi zasnovami tistega dela človeškega spoznavnega aparata, ki temelji na racionalnosti in logičnem sklepanju. Prvi korak na tej poti je predstavljalo natančno raziskovanje pojmov razuma in intuicije ter njunega vzajemnega razmerja. Že Liang Shuming, eden osrednjih predstavnikov prve generacije modernega konfucijanstva, se je veliko ukvarjal s pojmom intuicije, ki jo je poimenoval s terminom zhijue. $^{13}$

Etimološke študije so pokazale (An, 1997, 337), da ta termin v konfucijanskih klasikih še ni obstajal in da gre za moderni prevod zahodnega izraza »intuicija«, ki je bil od vsega začetka tesno povezan s konotacijami Bergsonovega vitalizma. ${ }^{14}$ Tudi termin lixing, ${ }^{15} \mathrm{ki}$ označuje razum, se je v istem času razširil predvsem kot prevod zahodnega koncepta razuma, četudi $\mathrm{v}$ okviru neokonfucijanske filozofije najdemo sorodne pojme; tu velja omeniti predvsem Zhu Xijev termin xingli. Razmerje med razumskimi in intuitivnimi spoznavnimi metodami je že prej obravnavalo mnogo tradicionalnih filozofov, četudi so jih označevali $\mathrm{z}$ različnimi imeni. Kot eden prvih modernih teoretikov je Liang leta 1921 objavil esej, ${ }^{16}$ v katerem se je skozi primerjavo med Bergsonovo filozofijo in neobudistično teorijo čiste zavesti (weishi lun) med drugim ukvarjal z razčiščevanjem razmerja med razumom in intuicijo (Liang, 1924, 97-102). Kasneje istega leta je Liang objavil svoje osrednje filozofsko delo Kulturi vzhoda in

11 Ta postavka je relativna, saj je tudi Wang omenjal neokonfucijansko načelo razuma, ki se je manifestiralo v vseobsežni (torej tudi mentalni) strukturi (li); vendar je pri tem vselej poudarjal, da je razum zgolj del srčne zavesti, ki naj bi stvarnost oziroma zunanji svet bolj celostno prepoznavala $\mathrm{z}$ metodo introspekcije in intuicije. Po Wangu ima razum oziroma mentalna struktura v srčni zavesti enak položaj kot objekti zunanje stvarnosti: »Izven srčne zavesti ni ne zakonitosti ne stvari (無心外 之理, 無心外之物)《. (Wang, 1929, I/8b).

12 良知.

13 直覺.

14 Osrednja Bergsonova dela so bila v kitajščino prevedena na pragu prejšnjega stoletja (An, 1979, 337).

15 Soroden moderni termin je tudi lizhi, ki ga prav tako prevajamo z izrazom razum.

16 Teoretiki čiste zavesti in Bergson 唯識家與柏格森. 
zahoda ter njuni filozofiji (Dong xi fang wenhua ji qi zhexue), v katerem je podrobno in sistematično obrazložil svoj koncept intuicije (zhijue) in ga jasno razmejil od razuma ter poskušal dokazati, da sta ta dva koncepta drug drugemu nasprotna. Liang je šel celo tako daleč, da je trdil, da sta bila ta dva koncepta odločilna pri opredeljevanju razlike med zahodno in kitajsko kulturo, saj naj bi se v okviru prve pretežno uporabljal razum, v okviru slednje pa intuicija. Četudi se je v kasnejših letih od koncepta liangzhi zavestno distanciral, saj se ne pojavlja v nobenem od njegovih del, ki so izšla po letu 1934 (An, 1997, 338), velja vendarle omeniti, da se je v tem pogledu s svojim striktnim razmejevanjem in kontradiktornostjo obeh konceptov razlikoval od velike večine ostalih modernih konfucijancev, ki so si prizadevali prek raziskovanja in nadgrajevanja konfucijanske idejne tradicije obrazložiti komplementarnost obeh kognitivnih metod. Tovrstno dojemanje njunega vzajemnega razmerja je tudi večini zahodnih teoretikov tuje, čeprav se v običajnem popularnem razmišljanju koncept razuma ali racionalnosti pogosto enači z nasprotnim polom intuicije (Fricker, 1995, 181). Vendar je že Thomas Kuhn v Strukturi znanstvenih revolucij (1962) nazorno pokazal, da se koncept intuicije pravzaprav nahaja v osrčju racionalnega raziskovanja, saj izhaja iz prepričanja, da je intuicija osrednji katalizator teoretskih preobratov v znanosti.

Isto stališče si je po Liang Shumingu delila večina filozofov modernega konfucijanstva. Že drugi predstavnik prve generacije, Carsun Chang (Zhang Junmai), je v leta 1954 objavljenem delu Reason and Intuition in Chinese Philosophy izhajal iz predpostavke, po kateri je razumska metoda spoznavanja zunanjega sveta in pridobivanja znanja $v$ osrčju izvornega Konfucijevega nauka. Pri tem je citiral znameniti Konfucijev izrek, v katerem ta izpostavi: »Učenje brez razmišljanja je brezplodno, razmišljanje brez učenja pa nevarno« (Kongzi, 2012; Wei Zheng 15).

Chang je ta citat interpretiral kot spodbudo za razmišljanje s pomočjo razuma. $\mathrm{V}$ delu Mencija, ki je tako neokonfucijancem kot tudi modernim konfucijancem predstavljal osnovo za interpretacijo izvornega konfucijanstva, je izpostavil stališče, po katerem sta razum ${ }^{17}$ in pravičnost (kot eden temeljnih simbolov moralnosti) v enaki meri notranja lastnost vseh ljudi.

Zato pravim: vsi ljudje imamo enak okus za dobre jedi, enak sluh, ki uživa v istih tonih, enak vid, ki ljubi enako lepoto. Zakaj naj bi se naše srčne zavesti med seboj razlikovale? Kaj je torej to, v čemer so si naše srčne zavesti enake? Pravim, da sta to razum in občutek za pravičnost ... Zato pravim, da razum in

17 Mencij tu razum označuje s terminom $l i$, ki pomeni strukturo. Ta je namreč v okviru antičnega kitajskega pogleda na svet predstavljala vseobsežno urejenost, ki se manifestira tudi v človeški srčni zavesti in je ustrojena na isti način kot struktura zunanje resničnosti. Četudi se ta koncept razuma v marsikaterem pogledu razlikuje od konotacij, ki jih je ta pojem pridobil v razvoju evropske filozofije (prim. Rošker, 2011, 113-123), je bil kasneje (v 19. stoletju) uporabljen tudi kot prvi (in bistveni) del dvozložnice, s katero so Kitajci označevali »zahodni« tip razuma. 
pravičnost razveseljujeta mojo zavest, prav tako kot dobri okusi razveseljujejo moja usta (Mengzi, 2012; Gaozi 7).

Pri tem gre torej za zlitje racionalnih in moralnih elementov znotraj človeške zavesti. Za razliko od Liang Shuminga je Chang poudarjal ravno obratno, namreč da se $v$ tem videnju enote razuma in morale manifestira načelna in temeljna enakost prevladujočih struj zahodne in kitajske filozofije.

Izhajajoč iz tega prepričanja je $\mathrm{v}$ omenjenem eseju ${ }^{18}$ opisal razvoj ter specifične konotacije razuma in intuicije znotraj tradicionalne kitajske filozofije. Pri tem poudarja, da so bili kitajski teoretiki vselej zelo pozorni na moralne vrednote in so se zato posebej natančno osredotočali na raven, ki se manifestira v konceptu xing (prirojene lastnosti, »človeška narava«). Termina xing in li naj bi po njegovem mnenju kombinirali zaradi tega, ker so slednjega videli kot nujno umeščenega $\mathrm{v}$ človeško naravo kot celoto (Chang, 1960, 101). Po Zhangovem mnenju vprašanje razmerja med obema navedenima konceptoma znotraj kitajske filozofije zavzema podoben položaj kot problem razmerja med univerzalnostjo in partikularnostjo znotraj zahodne miselnosti. Pri tem izpostavlja, da so vse vplivne filozofske šole kitajske tradicije temeljile na racionalni osnovi (ibid., 102).

Spoznanje, pridobljeno s pomočjo intuitivnega dojemanja, je zanj zato globoko zakoreninjeno v kogniciji, volji in čustvih ter zato predstavlja sintezo. Zhang poudarja, da tovrstne sinteze ni mogoče ustvariti na osnovi raziskav, v katerih postavimo razum in intuicijo $\mathrm{v}$ medsebojno nasprotujoče si razmerje, temveč jo lahko vzpostavimo samo na osnovi mnogo širših izhodišč (ibid.).

To načelno prepričanje so v veliki meri delili tudi predstavniki druge generacije modernega konfucijanstva. V Fang Dongmeijevem in Xu Fuguanovem delu vprašanja, povezana $\mathrm{z}$ nadgrajevanjem in moderniziranjem tradicionalnih konceptov racionalnosti, zavzemajo razmeroma ozek del problematiziranj, saj sta bila v svojem raziskovanju bolj osredotočena na druge vidike filozofije in idejne zgodovine.

\section{Xu Fuguan in telesno spoznanje}

$\mathrm{Xu}$ je v tem kontekstu prevzel tradicionalni Mencijev koncept moralnega razuma (daode lixing), ki naj bi služil kot orodje uravnavanja ter vodstva človeškega življenja in človeških želja v okviru moralne srčne zavesti. Ta se kaže kot zavest dobrega in etičnega znotraj moralnega sebstva (benxin) (Xu, 2005, 178). Xujeve obravnave epistemologije

18 Temu eseju je leta 1960 sledil esej, v katerem se (izhajajoč iz načelno enakega stališča) ukvarja pretežno z obravnavo intuitivnih metod znotraj tradicionalne kitajske filozofije (Chang, 1960, 35-49). 
izhajajo iz njegove predpostavke, po kateri je ta zavest človeku prirojena. ${ }^{19}$ Realizacija moralnega delovanja $\mathrm{v}$ tem okviru namreč temelji na predpogoju, da posameznik spozna (ali uvidi), da je to, kar je človeku prirojeno, rezultat nebeškega mandata (tian ming). ${ }^{20}$ Ta namreč sodi h konceptom, ki jih je Konfucij po Xujevem mnenju iz pojmov, ki so sodili v območje zunanjih moralnih kodeksov in predpisov, transformiral med pojme, ki so hkrati opredeljevali človeško notranjost. Xu Fuguan je izpostavil, da so se moralne ideje pred izvornim konfucijanstvom manifestirale zgolj kot znanje o pravilnem in primernem obnašanju. Bile so torej zgolj nekaj, kar je bilo vpeto v odnose objektivnega sveta, in niso mogle veljati kot nekaj, kar bi posamezniku omogočalo ozaveščanje in mu odpiralo duri $\mathrm{v}$ njegov notranji svet. Šele prek Konfucijeve ustvarjalne reforme se je ta zunanji kodeks, ki je urejal objektivni svet, pretvoril in zaobjel tudi svet ozaveščene notranjosti. Takšna enota je posamezniku v okviru konfucijanskega nauka nudila možnost stremljenja $\mathrm{k}$ boljšemu (k izpopolnitvi). Tako se je oblikoval duh kitajske moralnosti, ki je imanentna in transcendentna hkrati. To poenotenje je po Xu Fuguanu temeljilo na metodi ponotranjenja tradicionalnih religioznih konceptov, ki so se transformirali tako, da so se iz abstraktnih zunanjih idej spremenili v simbole, ki so označevali različne oblike obstoja notranje moralne substance. Žal Xu ni nikjer podrobneje opisal konkretne epistemologije tovrstnega poenotenja, ali z drugimi besedami, ni obrazložil natančne metode oziroma prikaza postopkov, prek katerih lahko ljudje dosežemo tovrstno identifikacijo. V tem kontekstu je Xu Fuguan sicer uvedel novo spoznavno metodo, ki jo je poimenoval z izrazom tiren (telesno spoznavanje) oziroma tizhi (znanje, pridobljeno prek telesa). Pri tej spoznavni metodi ne gre niti za intuicijo v običajnem pomenu niti za racionalno razmišljanje o logičnih relacijah med premisami in sklepi, temveč prej za »retrospektiven in aktiven proces, v katerem subjekt svojo moralno subjektivnost razloči od psevdosubjektivnosti človeških želja in jo v tem okviru razvija naprej« (ibid.).

$\mathrm{V}$ takšnem spoznavnem procesu se združita tako znanje in delovanje (zhixin heyi) kot tudi objektivnost in subjektivnost. Spoznavni subjekt se mora namreč, če želi pridobiti objektivno znanje, "potopiti« (ibid., 292) v objekt spoznavanja oziroma $\mathrm{v}$ to, kar je v njem možno spoznati, poleg tega pa sam akt spoznavanja vključuje tudi njegovo realizacijo v praksi. Pomemben element tega procesa je tudi koncept gongfu, ki hkrati vključuje subjektovo zmožnost spoznanja ter njegovo aktivno prizadevanje in trud za njegovo pridobitev. Šele prek aplikacije gongfuja lahko posameznik pridobi uvid v svoje transcendentno moralno sebstvo, ki je onkraj gongfuja. Spoznanje ali uvid, pridobljen na tak način, mora subjekt ponotranjiti in ga integrirati tako v svoje telo kot tudi v svoje racionalne dispozicije. Šele potem postane ta uvid popolnoma del

19 V običajnem dojemanju kitajske filozofije tudi ta predpostavka sodi k mencijanski idejni dediščini; a $\mathrm{Xu}$ je poskušal dokazati, da jo je mogoče najti že v delu samega Konfucija. 
njegovega znanja. V tem primeru se ločnica med znanjem in spoznavnim subjektom popolnoma zabriše in utelešenje tega, kar je spoznano, postane predpogoj za njegovo dejansko in popolno spoznanje. Ni Peimin Xu Fuguanu v tem kontekstu sicer očita, da je njegov koncept utelešenja neizdelan $(\mathrm{Ni}, 2002,291)$, vsekakor pa je ideja takšnega »telesnega spoznavanja« filozofsko precej zanimiva, četudi je Xu sam nikoli ni posebej natančno izdelal oziroma nadgradil; zato je bila (in je še) kasneje pogosto predmet nadaljnjih raziskav s strani sodobnih kitajskih teoretikov. ${ }^{21}$

\section{Holistična epistemologija Fang Dongmeija in primarnost čustev}

Za Fang Dongmeija je bil razum osnovan v racionalni strukturi (li) vesoljstva, ki pa je hkrati s to racionalnostjo opredeljena tudi $z$ delovanjem občutenja (qing). Fang je izhajal iz predpostavke, po kateri gre pri obeh elementih za korelativno in komplementarno binarno kategorijo, ki izvira iz skrajnega tečaja (taiji) in tvori (znotraj ontoepistemološke celovitosti, ki je značilna za klasično kitajsko idejno tradicijo) tako osnovo filozofskega mišljenja kot tudi temelj bivanja kot takega (Li Chengyang, 2002, 264). Medtem ko je »li « absolutni in najvišji izraz objektivnih pojavnosti, je »qing « zanj temeljna lastnost subjektivnosti. In ker Fang Dongmeijev koncept »življenja« v sebi združuje oba pojma, je popolnoma jasno, da nosi v sebi tudi pomen preseganja ločnice med subjektom in objektom (Fang, Li, 1989, III/894). V svojem delu Tri vrste filozofske modrosti (Zhexue san hui) pojma »li« in "qing « združi tudi v enoten epistemološki koncept »občutenega razuma (qingli)«, ki v svoji združitvi občutja in racionalnosti predstavlja fundamentalno in najprvobitnejšo srž oziroma osnovo spoznanja ter s tem »seme modrosti« (zhihui chongzi) (ibid.).

Koncepta qing in li zato zanj predstavljata komplementarno celoto, v kateri sta oba dejavnika v soodvisnem in korelativnem razmerju:

Qingli sodi med prvobitne simbolne podobe znotraj sistema filozofske terminologije. Qing nastane v povezavi z lijem in lijev obstoj je zopet odvisen od qinga. V svojem čudotvornem delovanju krožita drug okrog drugega in sta drug drugemu izvorni razlog. Območje njunega skupnega obstoja lahko prepoznamo s pomočjo intuicije, vendar ga je težko izraziti oziroma pojasniti (Fang, 2007, 2).

Četudi qingli vključuje tako razum kot občutja, ga je torej mogoče spoznati samo $\mathrm{z}$ intuitivno in ne $\mathrm{z}$ racionalno ali analitično metodo. Ta njegova epistemološka razsežnost se zato ne odraža zgolj v območju zaznavanja, temveč tudi v območju

21 Pri tem velja omeniti zlasti študije nekaterih predstavnikov tretje generacije modernega konfucijanstva, posebej Tu Wei-minga in Cheng Chung-yinga. 
posredovanja, saj gre za pojem neizrazljivosti, ki presega pomenske distinkcije, ki opredeljujejo konkretni svet človeškega življenja:

Sfera qinglija je hkrati oddaljena in bližnja, globoka in površinska, odkrita in zakrita. Zunaj nje ni mogoče nič uzreti in ustroj njene notranjosti lahko opredelimo s pomočjo sluha, vida in nege osebnosti (ibid.).

In vendar človek za svoj konkretni obstoj in za svoje konkretno življenje potrebuje oboje, tako qing kot li: „Človeško življenje je pogojeno s qingom in človeška eksistenca z lijem« (ibid.). Razum sam po sebi (torej ločeno od občutja) zanj predstavlja tretjo raven razvoja osebnosti (od skupaj šestih); to je raven, ki ustreza človeškemu obvladovanju naravnega zunanjega sveta in se manifestira v kulturi znanosti. Fang sicer priznava, da je ta vidik človeškega razvoja pomemben, vendar hkrati opozarja na to, da mora človeštvo stremeti k še višjim sferam umetnosti (lepote), morale (dobrote) in popolnosti (harmonije), torej $\mathrm{k}$ sferam, do katerih človek brez intuitivnega (moralnega) znanja nima dostopa (Fang, Li, 1989, III/904-906).

\section{Tang Junyi in čutna kompatibilnost}

Kot vsi moderni konfucijanci je tudi Tang Junyi v svoji epistemologiji izhajal iz pojma imanentne transcendence, ki ga je opredelil na osnovi svojih interpretacij neokonfucijanske šole zavesti ( $x$ in $x u e) .{ }^{22}$ Njegova epistemologija je zato tesno povezana z njegovo ontologijo, saj vidi svet kot metafizično realnost, ki je imanentna v vsem, kar $\mathrm{v}$ vesoljstvu obstaja, in ki poseduje moralne kvalitete (Sin, 2002, 306). Tako je osrednja konfucijanska krepost sočlovečnosti (ren) že sama po sebi del strukture kozmosa in njeno prepoznavanje, ki je, kot bomo videli, hkrati utelešenje in ponotranjenje ter se kaže v moralnem delovanju posameznika.

Srčna zavest $(x i n)$ kot nujni in konstitutivni del moralnega sebstva jeključni element spoznavnega procesa. Ta se konstituira prek njene funkcije »čutne kompatibilnosti« (gantong), ${ }^{23}$ ki sloni tako na čustvih kot tudi na razumu in volji. Združitev vseh teh dejavnikov pa je pogojena s "pravilnim dojemanjem «, ki mora potekati v skladu z vseprevevajočim, razumnim strukturnim načelom $(l i) .{ }^{24}$ Ko gre za spoznavanje drugega človeškega bitja, mora čutna kompatibilnost temeljiti tudi na empatiji.

22 Ta šola se v strokovni literaturi pogosto imenuje tudi »Šola Luja in Wanga«, in sicer po Lu Jiuyuanu (alias Lu Xiangshanu) in Wang Yangmingu. Ta šola se večinoma označuje kot idealistična, četudi je kategoriji idealizma in materializma problematično brezpogojno prenašati na kitajsko filozofijo. Nalepko idealizma si je prislužila s tem, da se večinoma ukvarja z raziskovanjem funkcije spoznavne srčne zavesti in njene kultivacije (prim. Sin, 2002, 305). 
Spoznavanje na osnovi čutne kompatibilnosti Tangu predstavlja tudi epistemološki predpogoj za prehajanje med različnimi obzorji (jing $)^{25}$ oziroma za razvoj od nižjih $\mathrm{k}$ višjim obzorjem. Tudi sam koncept obzorja zanj namreč ni zgolj ontološki in aksiološki, temveč hkrati epistemološki koncept.

Tangovo obravnavanje razuma je neločljivo povezano s konceptom moralnega sebstva, kot ga je izdelala šola srčne zavesti.

To, kar sam razumem pod terminom razum (lixing), ${ }^{26}$ lahko označim kot strukturo, ki je združljiva s strukturo prirojene narave, oziroma kot enotnost strukture $(l i)$ in prirojene narave. Kitajsko konfucijanstvo je razum poimenovalo $\mathrm{z}$ izrazom $x i n g l i{ }^{27}$ ta je razlog za to, da se moralno sebstvo, tj. duhovno oziroma moralno sebstvo, vzpostavi prek esence oziroma substance samega sebe (Tang, 1986, 254).

Tudi za Tanga je razum torej osnova moralnega sebstva, ki ga označi kot »transcendentno razumno sebstvo« (chaoyuede lixing ziwo, ibid.). Tang človeško moralno življenje dojema kot nekaj, kar zahteva zavestno obvladovanje samega sebe, in nekaj, kar je skupno vsem človeškim bitjem. Ta mencijanska univerzalnost človeške moralnosti z vidika epistemologije se ne kaže zgolj v kognitivnih zmožnostih razuma, temveč tudi v empiričnem spoznavanju sveta, ki temelji na čutnih organih.

Če pogledam $z$ vidika realnega sveta, potem vidim, da je vsako delovanje moje srčne zavesti povezano $\mathrm{z}$ mojim telesom. Zato lahko prek svojih spoznavnih aktivnosti, ki potekajo prek mojih čutnih organov, enakovredno spoznavam vse, kar obstaja. Če prek svojih čutnih organov zaznavam svoje telo in telesa drugih ljudi, se mi vsi prikažejo kot enakovredni deli vsega, kar obstaja. Moje čutno pogojeno spoznavanje je univerzalno tako glede mojih realnih soljudi kot tudi glede mojega lastnega telesa. $\mathrm{Z}$ vidika mojega lastnega realnega telesa pa lahko dojamem tudi manifestacijo obstoja transcendentne moralne zavesti srca. Iz tega lahko sklepamo, da tudi drugi realni ljudje razpolagajo z možnostjo dojetja manifestacij tovrstne moralne zavesti. Ta moj sklep temelji po eni strani na dejstvu, da sem konkreten človek, ki se nahaja v realnosti, po drugi pa na prepričanju, da se spoznanje, ki poteka prek mojega telesa, nanaša tudi na transcendentno substanco srčne zavesti (Tang Junyi, 1985, 110).

Pri tem moramo opozoriti na dejstvo, da Tang tu ne govori o intersubjektivnosti. Tang ni mislil, da obstaja skupni duh ali skupna zavest v smislu enakih ciljev ali intencij

25 境.

26 理性.

27 性理. 
vseh ljudi, temveč govori o transcendenčnem duhu posameznika, ki se združuje z drugimi prek procesa transcendence (Sin, 2002, 313). Ta transcendenca je možna zato, ker človeška srčna zavest tvori enoto $\mathrm{z}$ vesoljstvom.

Tangova epistemologija vsebuje tako spoznavno teorijo kot tudi teorijo modrosti. $\mathrm{V}$ obeh se razum in intuicija medsebojno prepletata; na osnovi tega vzajemnega prepletanja in medsebojnega vplivanja različnih segmentov in mehanizmov srčne zavesti je vzpostavil teoretsko zanimivo in inovativno hipotezo ustvarjalnosti modrosti (zhihuide chuangzaoxing, Han, Zhao, 1994, 56). Svoje teorije je poskušal utemeljevati $z$ metodami moderne analitične filozofije. To, kar imenuje »znanje« (zhishi), se nanaša na koncepte oziroma ideje, sklepanje, logične kognitivne zakonitosti in empirično intuicijo. »Modrost « pa je zanj »čudežna ustvarjalnost« (shenmiaode chuangzaoxing); to je inovativno mišljenje, ki je ciljno usmerjeno in presega samo znanje. Pri tem gre za vrsto intuitivnega mišljenja, ki pa ni niti zgolj čisto empirično niti čisto razumsko. To je vrsta mišljenja, ki lahko uporabi že pridobljeno znanje, vendar pred tem tudi samostojno odloča, ali bo to storilo ali ne. V tem procesu je znanje preseženo, a hkrati integrirano. V obeh teorijah igra osrednjo vlogo tudi morala, ki je osnova sebstva in $s$ tem srčne zavesti.

Kljub prizadevanju za takšno interpretacijo konotacijskih spektrov pojmov racionalnosti, intuicije, zaznavanja, dojemanja, mišljenja in morale, ki bi omogočila plodno nadgradnjo novega, moderni dobi ustrezajočega koncepta kitajskega razuma, pa Tangu ni uspelo vzpostaviti konsistentne in v sebi zaključene teorije tradicionalnega razuma. V njegovih tozadevnih spisih naletimo na številne logične nedoslednosti, ki jih izpostavljajo tudi sodobni raziskovalci in interpreti njegovih del. Han Qiang in Zhao Guanghui $(1994,57)$ mu očitata, da nikjer ne vzpostavi jasnega sosledja med empirično intuicijo, sodbami in sklepi ter racionalno intuicijo. Ko govori o tem, da ustvarjalnost modrosti znanje uporablja in ga hkrati presega, po eni strani trdi, da lahko racionalna intuicija neposredno pronica skozi vzorce, ki so se vzpostavili na osnovi sinteze predpostavk, in tako neposredno pride do veljavnih sklepov. To bi seveda pomenilo, da je racionalna intuicija nad logičnim razumom. Vendar Tang po drugi strani izpostavlja, da čista racionalna intuicija privede samo do znanja in nikakor ne do modrosti, saj naj bi bilo v njenem okviru predvideno zgolj nesklepčno mišljenje. Tudi njegov koncept »čudežno ustvarjalne modrosti« ni nikjer predmet podrobnejše analize ali celo utemeljitve. Edino, kar je pri njej jasno, je, da naj bi temeljila na moralni srčni zavesti, ki je nujni del človeškega sebstva ter deluje hipno in nezavedno.

Tudi Tangov zgoraj orisani model enotnosti posamičnih individualnih srčnih zavesti je problematičen. S pomočjo te enotnosti je Tang izdelal svoj koncept neskončne srčne zavesti, ki je enaka vesoljstvu. Vendar pa Sin Yee Chan $(2002,315)$ v 
tem kontekstu opozarja, da poenotenje še tako številnih posamičnih srčnih zavesti ne more brez nadaljnjega privesti do vzpostavitve neskončne srčne zavesti.

\section{Mou Zongsan: intuitivni razum je človeška in ne zgolj Božja lastnost}

Mou Zongsan je poskušal pozicijo razuma znotraj tradicionalne kitajske miselnosti opredeliti skozi primerjavo med zahodno in kitajsko kulturo, ki po njegovem mnenju predstavljata različne oblike reprezentacij človeškega razuma. V kitajski kulturi naj bi prevladala »funkcionalna oziroma intenzivna« (lixingzhi yunyong biaoxian), ${ }^{28} \mathrm{v}$ zahodni pa »konstruktivna oziroma ekstenzivna reprezentacija» (lixingzhi jiagou biaoxian $)^{29}$ (Mou, 1995, 544-553). ${ }^{30}$ Razlika med obema reprezentacijama je v glavnem primerljiva $\mathrm{z}$ diferenciacijo med praktičnim in teoretičnim razumom.

»Razum«, ki se pojavlja znotraj funkcionalne reprezentacije, je seveda praktični razum. Vendar pri tem ne gre za nekaj abstraktnega, temveč za nekaj konkretnega, življenjskega. Zato je t. i. razum, o katerem tukaj govorimo, seveda identičen z moralnostjo, ki se nahaja znotraj osebnosti (ibid., 544$545)$.

Vendar pa Mou za razliko od Kanta funkcionalnemu razumu pripisuje tudi možnost intuitivnega razuma (zhide zhijue), medtem ko Kant ${ }^{31}$ tega potenciala ne priznava oziroma ga ne pozna. ${ }^{32}$

Mou je poudarjal, da ima Kantovo neupoštevanje možnosti človeškega dostopa do intuitivnega razuma še bolj daljnosežne teoretske implikacije. Mou Zongsan je namreč menil, da je vpeljava tega koncepta $\mathrm{v}$ epistemologijo nujna, saj ostaja brez njega celoten metafizični konstrukt sveta in človeškega bivanja v njem na zelo trhlih nogah. $\mathrm{V}$ bistvu se brez konceptualizacije človeškega intuitivnega razuma podre celoten Kantov konstrukt avtonomnega subjekta, po drugi strani pa je brez njega tudi celotna

28 理性之運用表現.

29 理性之架構表現.

30 Lee Ming-Huei $(2001,47)$ opozarja, da Mou v svojem leta 1962 objavljenem delu Filozofija zgodovine (Lishi zhexue) ta pojmovni par označuje z izrazoma »duh sintetične racionalnosti« oziroma »duh analitične racionalnosti« (2. poglavje tretjega dela). Četudi se ta izraza razlikujeta od zgoraj omenjenih terminov, sta po Leejevem mnenju oba pojmovna para vsebinsko identična.

31 Po Moujevem mnenju to ne velja zgolj za Kanta, temveč za celotno zahodno idejno tradicijo, v kateri so spoznavne možnosti intuitivnega razuma vselej rezervirane izključno za Boga. S tem je bil intuitivni razum (enako kot nesmrtna duša ali svobodna volja) na zahodu vselej dojet zgolj kot postulat in ne kot resničnost. (Za Moujev dokaz tega, da je avtonomna in svobodna volja del dejanske pojavnosti (chengxian) in ne zgolj postulat, glej Mou, 1983, 77ff.). Posledica tega je tudi prevladujoče ločevanje resničnosti v sferi pojavnosti in substance (Han, Zhao, 1994, 170).

32 Za podrobnejšo obravnavo tega problema glej Rošker, 2016, poglavje o Mou Zongsanu ter poglavje o razumu in intuiciji. 
tradicionalna kitajska filozofija oropana svojega idejnega temelja. Zato je koncept človeškega intuitivnega razuma pravzaprav v ospredju ali središču Moujeve filozofije. Kot izpostavi Sébastien Billioud (2012, 70), prav ta koncept predstavlja osrednji steber njegove reinterpretacije kitajske in nadgradnje oziroma preseganja Kantove filozofije:

Če ne priznamo, da ima človek v svojem omejenem obstoju možnost intuitivnega razuma, potem glede na Kantovo interpretacijo pomena in vloge tovrstne intuicije celotna kitajska filozofija sploh ni možna. In ne samo to: $v$ tem primeru ostaja tudi celotna Kantova moralna filozofija prazno besedičenje. S tem se nikakor ne morem sprijazniti. Pogoji za možnost intuitivnega razuma morajo biti vzpostavljeni s pomočjo kitajske filozofske tradicije (Mou, 1971, Predgovor/2).

Po Mouju gre pri »konstruktivni reprezentaciji« za idejni model, ki temelji na nasprotju med subjektom in objektom in ki se manifestira v matematiki, logiki, znanosti in sistemu politične demokracije. »Funkcionalna reprezentacija « pa je zanj osnovana na odsotnosti te ločnice in se kaže predvsem v moralnih in religioznih dejanjih (Lee, 2001, 67).

Po Moujevem mnenju $(1995,549)$ je v zahodni kulturi prevladala prva, v kitajski pa slednja oblika reprezentacije razuma. $\mathrm{V}$ tem vidi tudi razlog za to, da kitajska tradicija ni bila sposobna razviti potenciala za moderno obliko demokracije in znanosti, četudi je po drugi strani razvila izjemno izdelan sistem morale in etike.

Če povzamemo, se prispevki konstruktivne reprezentacije kažejo predvsem $\mathrm{v}$ dveh stvareh, namreč v znanosti in demokratični politiki. Že več desetletij se vsi kitajski intelektualci razburjajo zaradi tega. Le zakaj Kitajska ni mogla razviti znanosti in demokratične politike? Naš odgovor se glasi, da je to zaradi tega, ker v njej ni dovolj prevladala konstruktivna reprezentacija razuma. Kitajska kultura pozna zgolj funkcionalno reprezentacijo razuma (ibid.).

Moujev koncept intuitivnega razuma je pomemben tudi kot aksiološka nadgradnja zahodnega koncepta racionalnosti. Intuitivni razum je zanj neposredna oblika razuma oziroma intelekta (Han, Zhao, 1994, 169): »Intuitivni razum je racionalen in ni zgolj stvar »občutenja«. A ta razum je neposreden in ni razločevalen niti logičen« (Mou, ibid., 170).

To pomeni, da je intuitivni razum takšna oblika razuma, ki je »višja« oziroma kompleksnejša od zaznave na podlagi občutenja, empiričnega dojemanja ali logične racionalnosti. Pri tem gre torej za osnovno metodo pridobivanja spoznanj o sferi pomenov in vrednosti (Mou, 1971, 19).

Intuitivni razum ni enak občutenju, kajti to se nanaša na objekte zunanjega sveta in je zato zgolj pasivni prejemnik. Intuitivni razum pa nima objekta in 
pri njem ni mogoče govoriti o razliki med subjektom in objektom spoznanja. On je sam po sebi aktivnost substance jasne srčne zavesti; je refleksija samega sebe (ibid.).

Po Moujevem mnenju so takšno metodo dojemanja razvile vse tri najpomembnejše filozofske šole kitajske idejne tradicije. V konfucijanstvu so jo poimenovali osnova moralne srčne zavesti ali moralno sebstvo (daode benxin), v daoizmu srčna zavest poti (dao xin) in v budizmu resnična večna zavest (zhenchang xin).

$\mathrm{V}$ delu Pojavi in stvari na sebi (Xianxiang yu wu zishen) je Mou prek svoje reinterpretacije konfucijanske tradicije poskušal razložiti koncept stvari na sebi, in to ne zgolj kot epistemološki, temveč tudi kot vrednostni koncept.

$\mathrm{Za}$ konfucijance se je metafizični noumenon (substanca) vzpostavil neposredno izhajajoč iz moralne srčne zavesti ... Ljudje moramo prek svoje moralne srčne zavesti neposredno priti do manifestacije notranje moralne substance. Svoje sebstvo vzpostavimo prek soočenja $s$ to manifestacijo substance. Ta substanca, ki se manifestira, je neposredno moralna in hkrati metafizična. Zaradi tega lahko svoj moralni vrednostni pomen ohranja tudi v svojem prevevanju vseh stvari in objektov (vedenjskih in ontoloških). V tem okviru so vse stvari in vsi objekti stvari in objekti »v sebi«. Pri tem ima pojem »biti v sebi« moralni in vrednostni pomen (Mou, 1975, 435-436).

Mou Zongsan je bil namreč prepričan, da zgolj spoznavnoteoretsko razumevanje tega pojma nikakor ne zadošča za utemeljitev Kantove transcendentalne razlike med pojavom in stvarjo na sebi, kajti v Kantovem sistemu ta vselej ostaja onkraj človeškega spoznavnega potenciala. Za razrešitev te problematike postavi Mou tezo, po kateri je človek sicer končen, vendar ima tudi dostop do neskončnega. Ta dostop vidi prav v lastnosti intuitivnega razuma (zhide zhijue).

Ideje nastajajo samo na začetku, še preden se je razkrilo izvorno sebstvo. ${ }^{33}$ To je takrat še slepo in preobraženo v spoznavno zavest. V tej fazi se vse aktivnosti zavesti dogajajo zgolj na ravni prirojenih možnosti zaznave. Toda izvorno sebstvo se mora zaradi sebi lastne sile vibracij nujno prej ali slej razkriti. Zaradi tega, ker je možen intuitivni razum, se mora $\mathrm{v}$ trenutku popolnosti nujno razkriti $\mathrm{v}$ vsem svojem blišču. Takrat se spreminjajoče se ideje ponovno vrnejo $\mathrm{v}$ srčno zavest in pojavi se »brezpomenski pomen«, ki je prav tako nujno možen in dosegljiv. »Sveta volja« je prav ta »brezpomenski pomen«. Zato mora biti človek končen in brezkončen hkrati (Mou, 1975, 79).

Intuitivni razum nam tako omogoča, da »stvar po sebi« za nas ne predstavlja več nekakšnega za vselej nedoseženega »onostranstva«, temveč vrednostno sfero, 
ki se nam lahko prikaže neposredno prek našega zavedanja svobode. Mou vztraja pri predpostavki, da mora biti Kantov pojem noumena »vrednostni koncept v zelo močnem pomenu« (ibid., 8), kajti samo na tej osnovi je mogoče dojeti razlikovanje med njim in konceptom phenomenona (Tang, 2002, 334). Pri konceptu noumena torej nikakor ne gre za koncept »izvorne pojavnosti«. Pri njem ne gre za nikakršno objektivno dejstvo, ki se mu lahko nenehno bližamo, ne da bi ga kadarkoli dosegli. Noumenon je nekaj, čemur se nikoli ne moremo približati na ravni naših občutij ali na ravni razumskega razumevanja. Torej gre pri njem nujno za transcendentalen koncept (ibid.).

Vendar Mou s tem, ko ljudem pripiše intuitivni razum, za razliko od Fichteja Kantovega sistema ne želi izničiti, temveč dodatno utemeljiti. Za Mouja je Kantovo razlikovanje filozofsko nujno; vse, kar potrebuje, je zgolj reinterpretacija. Moujeva teza o možnosti doseganja »stvari na sebi« je združljiva s Kantovo omejitvijo spoznanja na pojave (Lee, 2001, 70), kajti intuitivnega razuma ne vidi kot vrsto spoznanja, temveč kot dojetje vrednot. Tang Refeng izpostavi $(2002,334)$, da je Moujev intuitivni razum (intellectual intuition) ključen za celoten sistem njegove moralne metafizike. Za Mou Zongsana je moralna metafizika diskurz, ki se nanaša na obstoj vseh bitij z moralno substanco, ki se izraža v moralni srčni zavesti. Zato je moralna substanca, ki je hkrati neskončna srčna zavest, zanj tudi metafizična. Neskončna srčna zavest namreč vključuje oboje, tako moralno substanco, ki človeku odpira vrata, ki vodijo $\mathrm{v}$ domeno morale (ibid.), kot tudi metafizično substanco, ki omogoča eksistenco v sferi noumena.

\section{Zaključek}

Moralno sebstvo, »opremljeno « $\mathrm{z}$ neskončno srčno zavestjo intuitivnega razuma, predstavlja enega možnih odgovorov modernih konfucijancev na globalna vprašanja sodobnega časa, povezana $\mathrm{z}$ dilemami modernega subjekta, ki je, ujet $\mathrm{v}$ kompleksnost tehnologij profitno naravnanega naravnega sveta, pozabil na etične razsežnosti, ki opredeljujejo njegovo človeškost in spoznavanje resničnosti. Če torej kitajska družba želi stopiti na pot modernizacije $\mathrm{v}$ okviru lastnega kulturnega konteksta in če torej želi v svojo kulturo integrirati elemente, potrebne za razvoj moderne demokracije in znanosti, se mora po mnenju Modernih konfucijancev transformirati v smislu razvoja tovrstnih epistemoloških modelov. Če noče postati duhovna kolonija, mora $\mathrm{v}$ ta namen nadgraditi tiste koncepte lastne idejne tradicije, ki predstavljajo potencial za razvoj takšnih modelov. Četudi se mora kitajska kultura v procesu modernizacije transformirati, lahko pri tem še vedno ohrani svoj prvotni značaj. 


\section{Literatura}

An, Y., Liang Shuming and Henri Bergson on Intuition: Cultural Context and the Evolution of Terms, Philosophy East and West, 47/3, 1997, str. 337-362.

Chang, C., Chinese Intuitionism: A Reply to Feigl on Intuition, Philosophy East and West, 1960, str. 35-49.

Fang, D. 方東美, Zhexue sanhui 哲學三慧 (Tri vrste filozofske modrosti), Tajpej 2007.

Fang, K. 方克立, Li, J. 李錦全 (ur.), Xiandai xin ruxue yanjiu lunji 現代新儒學研究 論集 (Zbirka študij o modernem konfucijanstvu), Peking 1989.

Fricker, A., Intuition and Reason, The Philosophical Quarterly, 45/179, 1995, str. 181189.

Han, Q. 韓, Zhao, G. 趙光輝, Wenhua yishi yu daode lixing - Gang Tai xin rujia Tang Junyi yu Mou Zongsande wenhua zhexue 文化意識與道德理性 - 港台新儒家 唐君毅與牟宗三的文化哲學 (Kulturna zavest in moralni razum - hongkonškotajvanska moderna konfucijanca Tang Junyi in Mouzongsan ter njuna filozofija kulture), Šenjang 1994.

Kongzi 孔子 (Mojster Kong, Konfucij), Lunyu 論語 (Razprave), Chinese Text Project. Pre-Qin and Han, http://chinese.dsturgeon.net/text.pl?node=3925\&if=en [7. 7. 2012].

Kuhn, T., The Structure of Scientific Revolutions, Chicago 1962 (1970).

Lee, M. (Li Minghui 李明輝), Der Konfuzianismus im modernen China, Leipzig 2001.

Li, C., Philosophy of Life, Creativity and Inclusiveness, v: Contemporary Chinese Philosophy (ur. Cheng C.-Y., Bunnin, N.), Oxford 2002, str. 258-280.

Liang, S. 梁漱, Liang Shumin sanshi qian wenlu 梁漱溟三十前文錄 (Liang Shumingova dela pred njegovim tridesetim letom), Šanghaj 1924.

Mengzi 孟子 (Mojster Meng, Mencij), Chinese Text Project. Pre-Qin and Han, http:// chinese.dsturgeon.net/text.pl?node=3925\&if=en [7. 7. 2012].

Ni, P., Practical Humanism of Xu Fuguan, v: Contemporary Chinese Philosophy (ur. Cheng, Ch.-Y., Bunnin, N.), Oxford 2002, str. 281-304.

Mou, Z., Zhide zhijue yu Zhongguo zhexue 智的直覺與中國哲學 (Intuitivni razum in kitajska filozofija), Tajpej 1971.

Mou, Z. 牟宗三, Xianxiang yu wu zishen 現象與物自身 (Pojavi in stvari po sebi), Tajpej 1975.

Mou, Z.牟宗三, Zhongguo zhexue shijiu jiang 中國哲學十九講 (Devetnajst predavanj iz kitajske filozofije), Tajpej 1983. 
Mou, Z. 牟宗三, Zhengdao yu zhidao, di san zhang 政道與治道, 第三章 (Načelo politične legitimacije in načelo vladanja, 3. poglavje), v: Xiandai xin ruxue xuéan 現代新儒家學案 (Pregled akademskega dela modernih konfucijancev) (ur. Fang, K. 方克立, Li J. 李錦全), Peking 1995.

Ng, O., The Imperative of Understanding: Chinese Philosophy, Comparative Philosophy, and Onto-Hermeneutics - A Tribute Volume Dedicated to Professor Chung-ying Cheng, Journal of Chinese Philosophy 38 (1), 2011, str. 151-156.

Rošker, J. S., Searching for the Way: Theory of Knowledge in pre-Modern and Modern China, Hong Kong 2008.

Rošker, J. S., Li: struktura kot temeljna epistemološka paradigma tradicionalne kitajske filozofije, Ljubljana 2011.

Rošker, J. S., pod geslom: Epistemology in Chinese Philosophy, The Stanford Encyclopedia of Philosophy (ur. Zalta, N. E.), 2015, http://plato.stanford.edu/ archives/win2015/entries/chinese-epistemology/ [1. 1. 2016].

Sin, Y. C., Tang Junyi: Moral Idealism and Chinese Culture, v: Contemporary Chinese Philosophy (ur. Cheng, Ch.-Y., Bunnin, N.), Oxford 2002, str. 235-346.

Tang, J. 唐君毅, Daode ziwozhi jianli 道德自我之建立 (Vzpostavitev moralnega sebstva), Tajpej 1985.

Tang, J. 唐君毅, Wenhua yishi yu daode lixing 文化意識與道德理性 (Kulturna zavest in moralni razum), Tajpej 1986.

Tang, R., Mou Zongsan on Intellectual Intuition, v: Contemporary Chinese Philosophy (ur. Cheng, Ch.-Y., Bunnin, N.), Oxford 2002, str. 235-346.

Wang, S. 王守仁, Yangming xiansheng jiyao 陽明先生集要, 12, (Zbirka najpomembnejših poudarkov Wangove misli), Šanghaj, 1929.

Xia, Z. 夏甄陶, Zhongguo renshilun sixiang shi 中國認識論思想史稿, 上, 下 (Oris zgodovine kitajske epistemologije, 1. in 2. del), Peking 1996.

Xiong, S. 熊十力, Xiong Shili lunzhu ji zhi yi 熊十力論著集之一 (Zbrana dela Xiong Shilija, 1. del /Xin weishi lun/), Peking 1992.

$\mathrm{Xu}, \mathrm{F}$. 徐復觀, Zhongguo renxing lun shi 中國人性論史 (Zgodovina kitajskega dojemanja človeških prirojenih lastnosti), Peking 2005.

$\mathrm{Yu}$, J., Xiong Shili's Metaphysics of Virtue, v: Contemporary Chinese Philosophy (ur. Cheng, Ch.-Y., Bunnin, N.), Oxford 2002, str. 127-146. 
Jana S. Rošker

\section{Epistemologija modernega konfucijanstva na primeru druge generacije - med razumom in intuicijo}

Ključne besede: moderna kitajska epistemologija, spoznavna teorija, Xiong Shili, Liang Shuming, Feng Youlan, Fang Dongmei, Mou Zongsan, Xu Fuguan, Tang Junyi, razum, intuicija

Pričujoči članek kritično obravnava epistemološke teorije osrednjih predstavnikov intelektualne struje modernega konfucijanstva, ki se je na Kitajskem oblikovala na pragu prejšnjega stoletja. Avtorica analizira in interpretira njihove nadgradnje ter razvoje tradicionalne kitajske epistemološke predpostavke, po kateri je moralna kultivacija sebstva predpogoj za celovito znanje. Korelat te premise je v tem, da človeško zaznavanje ni samo razumsko, temveč tudi iracionalno, saj je med drugim opredeljeno z voljo, namero, željami in občutji. Moderni konfucijanci so predpostavljali, da je ista ločnica, ki je razmejevala razum od intuicije, ločevala tudi znanost od filozofije. Četudi niso nasprotovali znanosti kot taki, so bili vendarle nasprotniki scientizma. Zato so opozarjali, da znanost, katere cilj je zgolj spoznavanje objektov zunanjega naravnega sveta in ki uporablja izključno racionalne in analitične metodologije, nikoli ne bo zmožna odgovoriti na vprašanja, povezana s smislom življenja. Iz istega razloga znanost po njihovem mnenju tudi nikoli ne bo sposobna dejansko vplivati na svetovni nazor posameznika. Ločnica med razumom in intuicijo po njihovem mnenju namreč ne razmejuje zgolj znanosti od filozofije, temveč tudi sfero pojavnosti od sfere vrednot. 
Jana S. Rošker

\section{Modern Confucian Epistemology through the Lens of the Second Generation: Between Reason and Intuition}

Keywords: Modern Chinese epistemology, Theory of knowledge, Xiong Shili, Liang Shuming, Feng Youlan, Fang Dongmei, Mou Zongsan, Xu Fuguan, Tang Junyi, Reason, Intuition

The present paper critically introduces the epistemological thought of the crucial representatives of the $20^{\text {th }}$-century Modern Confucian thinkers. It aims to show their particular developments of the traditional Chinese tenet that the moral cultivation of the Self is a precondition for comprehensive knowledge. A corollary of this premise is that human perception is not only rational, but also irrational, in the sense of also being determined by will or intention, desires and feelings. They assumed that the same border that divided reason from intuition also divided science from philosophy. They were not opposed to science, but to scientism, arguing that science, which aims at the recognition of objects in the external natural world and applies an exclusively rational and analytical methodology, would never be able to solve questions connected to the meaning of life or to influence an individual's worldview. Whereas science explores fact, philosophy investigates meaning and values. The divide between reason and intuition did not merely separate science and philosophy (or natural sciences and the humanities), but also the sphere of phenomena from the sphere of values. 